Check for updates

Cite this: RSC Adv., 2019, 9, 39381

Received 14th September 2019

Accepted 14th November 2019

DOI: $10.1039 / c 9 r a 07397 c$

rsc.li/rsc-advances

\section{Thermostable iron oxide nanoparticle synthesis within recombinant ferritins from the hyperthermophile Pyrococcus yayanosii $\mathrm{CH} 1 \uparrow$}

\author{
Jiacheng Yu, (D) abc Tongwei Zhang, ${ }^{a b}$ Huangtao Xu, ${ }^{a b c}$ Xiaoli Dong, ${ }^{d}$ Yao Cai, ${ }^{a b}$ \\ Yongxin $\mathrm{Pan}^{\mathrm{abc}}$ and Changqian $\mathrm{CaO}^{\star a b c}$
}

\begin{abstract}
Thermostable nanoparticles have numerous applications in catalysis and in the oil/gas industry. However, synthesizing these nanoparticles requires expensive polymers. Here, a novel thermostable ferritin named PcFn, originally from the hyperthermophilic archaeon Pyrococcus yayanosii $\mathrm{CH}$, was overexpressed in Escherichia coli, purified and characterized, which could successfully direct the synthesis of thermostable magnetoferritins (M-PcFn) with monodispersed iron oxide nanoparticles in one step. Transmission electron microscopy and magnetic measurements show that the cores of the M-PcFn have an average diameter of $4.7 \mathrm{~nm}$, are well-crystalline and superparamagnetic. Both the PcFn and M-PcFn can resist temperatures up to $110{ }^{\circ} \mathrm{C}$, which is significantly higher than for human $\mathrm{H}$-chain ferritin (HFn) and $\mathrm{M}-\mathrm{HFn}$, and comparable to temperatures previously reported for Pyrococcus furiosus ferritin (PfFn) and M-PfFn. After heating at $110{ }^{\circ} \mathrm{C}$ for 30 minutes, PcFn and M-PcFn maintained their secondary structures and PcFn retained $87.4 \%$ of its iron uptake activity. This remarkable thermostability of PcFn and M-PcFn suggests potential applications in elevated temperature environments.
\end{abstract}

\section{Introduction}

Magnetic nanoparticles (MNPs) consisting of magnetite $\left(\mathrm{Fe}_{3} \mathrm{O}_{4}\right)$ or maghemite $\left(\gamma-\mathrm{Fe}_{2} \mathrm{O}_{3}\right)$ have been studied for applications at elevated temperatures, including in subsurface reservoirs ${ }^{1-4}$ and in catalysis., ${ }^{5,6}$ For example, superparamagnetic iron oxide nanoparticle dispersions can be applied as imaging agents for visualization of oil in underground oil reservoirs. ${ }^{7}$ These nanoparticles can be induced to move to the oil-water or airwater interface by a magnetic field, and the motion of magnetic nanoparticles at the interface can be detected by an external magnetic field which generates acoustic waves. ${ }^{8}$ In many cases, MNPs need to be coated with functional polymers to obtain optimal dispersibility and thermal stability, and limit magnetic interactions in aqueous mediums; examples include poly (2methyl-2-acrylamidopropanesulfonate-co-acrylic acid), ${ }^{1} \quad$ alkanedisulfamic acid ${ }^{5}$ and tetraethyl orthosilicate. ${ }^{6}$ However, these functional MNPs were fabricated using expensive polymer

\footnotetext{
${ }^{a}$ Biogeomagnetism Group, Paleomagnetism and Geochronology Laboratory, Key Laboratory of Earth and Planetary Physics, Institute of Geology and Geophysics, Chinese Academy of Sciences, Beijing 100029, P. R. China. E-mail: changqiancao@ mail.iggcas.ac.cn

${ }^{b}$ Innovation Academy for Earth Science, CAS, Beijing 100029, P. R. China ${ }^{c}$ College of Earth Sciences, University of Chinese Academy of Sciences, Beijing 100049, P. R. China

${ }^{d}$ Department of Geoscience, University of Calgary, Calgary, AB, T2N 1N4, Canada $\uparrow$ Electronic supplementary information (ESI) available: Additional figures. See DOI: $10.1039 / \mathrm{c} 9 \mathrm{ra07397c}$
}

stabilizers, limiting their large-scale production and practical applications.

Ferritin is an ubiquitous iron storage protein consisting of 24 subunits, which self-assembles into a spherical nanocage with an exterior diameter of $12 \mathrm{~nm}$ and an internal diameter of $8 \mathrm{~nm} .{ }^{9}$ Thus, it has been exploited as an excellent nanocontainer for synthesis of a variety of uniform-sized nanoparticles, including $\mathrm{Fe}^{10} \mathrm{Fe}_{3} \mathrm{O}_{4}{ }^{11} \mathrm{Co}(\mathrm{O}) \mathrm{OH},{ }^{12} \mathrm{Mn}_{3} \mathrm{O}_{4},{ }^{13} \mathrm{CaCO}_{3},{ }^{14} \mathrm{CdSe},{ }^{15} \mathrm{CoPt},{ }^{13}$ $\mathrm{ZnSe},{ }^{16}$ and $\mathrm{Au} .{ }^{17}$ Magnetoferritin is a synthetic derivate of ferritin, consisting of an apoferritin shell and a magnetic iron oxide core $\left(\mathrm{Fe}_{3} \mathrm{O}_{4}, \gamma-\mathrm{Fe}_{2} \mathrm{O}_{3}\right)$. The protein shell endows magnetoferritin with good dispersity and biocompatibility, and the magnetic core provides good superparamagnetism. This allows magnetoferritin to be monodispersed without extra modification, reducing its cost of production and simplifying the production procedures. Therefore, magnetoferritin serves as an excellent vehicle for biomedical applications, such as targeted drug delivery, delivery of contrast agents for early diagnosis of tumors, and cancer hyperthermia. ${ }^{\mathbf{1 8 - 2 1}}$ From perspective of application in subsurface, the small size (about $12 \mathrm{~nm}$ ) and superparamagnetism of magnetoferritin may make it easily detected with minimal retention through the porous mediums. In addition, ferritin has relatively high thermostability compared to most proteins. Most mesophilic ferritin cages, such as recombinant human $\mathrm{H}$ chain ferritin (HFn), can resist temperatures as high as $77{ }^{\circ} \mathrm{C}^{\mathbf{2 2}}$ indeed, this temperature is commonly used for ferritin purification. However, under some elevated temperature conditions, including underground reservoirs where the temperature is always above $80{ }^{\circ} \mathrm{C},{ }^{23}$ 
these mesophilic ferritins become unstable. To improve the thermostability of ferritin-based materials, several surface chemical modifications and gene mutation methods have been implemented. Yang et al. increased the $T_{\mathrm{m}}$ (denaturation temperature) of apo-red bean seed ferritin (OFN) from $73.12{ }^{\circ} \mathrm{C}$ to $78.16{ }^{\circ} \mathrm{C}$ with oligochitosan modification. ${ }^{24} \mathrm{Kim}$ et al. reported an $\mathrm{N}$-terminal fusion mutant of human L-chain ferritin maintaining about $60 \%$ concentration after heating at $72{ }^{\circ} \mathrm{C}$ for $30 \mathrm{~min}$ at both high $\left(1.3 \mathrm{mg} \mathrm{mL}^{-1}\right)$ and low $\left(0.2 \mathrm{mg} \mathrm{mL}^{-1}\right)$ protein concentrations. ${ }^{25}$ Nevertheless, these methods only slightly increased the thermostability of ferritins.

The discovery of hyperthermophilic organisms in extreme environments has paved the way for obtaining highly thermostable ferritins and magnetoferritins. Pyrococcus furiosus, is one of the most-studied hyperthermophilic archaeon, which was isolated from geothermally heated marine sediments with optimal growth temperature of $100{ }^{\circ} \mathrm{C}^{26}$ Biologists have created a number of highly thermostable biomaterials from this organism, including Pfu-DNA polymerase, ${ }^{27}$ which is widely used in high-fidelity PCR amplification. Recombinant ferritin from P. furiosus (PfFn) is an extremely thermostable protein, with no melting occurring (by differential scanning calorimetry) up to $120{ }^{\circ} \mathrm{C}^{\mathbf{2 8 , 2 9}}$ Mackenzie et al. used PfFn as a template for the synthesis of magnetic nanoparticles by improving the synthesis temperature, and obtained particles with significant enhancement of magnetic hysteresis compared with HFn-mineral composites. ${ }^{30}$ Moreover, the ferritin AfFn from the hyperthermophilic archaeon Archaeoglobus fulgidus, has also been studied ${ }^{31}$ and used for enzyme encapsulation. ${ }^{32}$ These hyperthermophilic ferritins have remarkably elevated thermal tolerance for ferritin cages. However, there are currently no reports in the literature showing the thermostability of ferritins from new hyperthermophilic organisms (aside from PfFn), indicating that hyperthermophilic ferritins need to be further investigated.

In this study, we report a novel ferritin (PcFn) from the hyperthermophile Pyrococcus yayanosii $\mathrm{CH} 1$, which was isolated from a vent field at a depth of $4100 \mathrm{~m}$ and characterized as the first obligate piezophilic hyperthermophilic microorganism (optima of $52 \mathrm{MPa}$ and $98^{\circ} \mathrm{C}$ )..$^{33-35}$ According to these extremely harsh living conditions, we hypothesized that the ferritin and magnetoferritin from $P$. yayanosii $\mathrm{CH} 1$ might be resistant to high temperatures. To test this hypothesis, we cloned and overexpressed the PcFn gene from hyperthermophile $P$. yayanosii $\mathrm{CH} 1$ in Escherichia coli (E. coli), and successfully used the purified PcFn protein for biomimetic synthesis of magnetoferritin $\left(\mathrm{M}-\mathrm{PcFn}_{5000}\right)$, with a loading factor of $5000 \mathrm{Fe} /$ cage. In addition, two other ferritins, HFn and PfFn, were also cloned, overexpressed in $E$. coli, and purified in order to synthesize the magnetoferritins $\mathrm{M}-\mathrm{HFn}_{5000}$ and $\mathrm{M}-\mathrm{PfFn}_{5000}$ for comparative study with PcFn and M-PcFn ${ }_{5000}$. To our knowledge, this is the first systematic study of the differences in thermostability between these three ferritin cages and their magnetoferritins. Furthermore, the crystalline structures and magnetic properties were also investigated between these different magnetoferritins, which has not previously been shown.

\section{Experimental}

\section{Materials}

Ammonium ferrous sulfate $\left(\left(\mathrm{NH}_{4}\right)_{2} \mathrm{Fe}\left(\mathrm{SO}_{4}\right)_{2} \cdot 6 \mathrm{H}_{2} \mathrm{O}\right)$ was purchased from Sigma-Aldrich (USA). Sodium chloride, Tris and $N, N, N^{\prime}, N^{\prime}$-tetramethylenebis(acrylamide) (TEMED) were obtained from Sangon Biotech (China). All experiments were performed using ultrapure water (MilliPore). Bovine serum albumin (BSA) was obtained from Thermo Scientific (USA).

\section{Preparation of recombinant ferritins}

Recombinant HFn was prepared as previously described. ${ }^{36}$ The gene sequences of two thermophilic ferritins, PcFn and PfFn, were identified and downloaded from GenBank, having respective gene IDs of 10837266 and 1468595. The obtained genes were modified for codon preference of $E$ coli and synthesized. Subsequently, the expression vector pET-22b, containing either PcFn or $P f F n$, was transformed into $E$. coli BL21 (DE3). We cultured the $E$. coli at $37{ }^{\circ} \mathrm{C}$ to an $\mathrm{OD}_{600}$ of 0.6 in ampicillin-containing liquid Luria-Bertani (LB) medium, and induced expression with $0.5 \mathrm{mM}$ isopropyl- $\beta$ - $d$-thiogalactoside (IPTG) overnight at $30^{\circ} \mathrm{C}$. The cells were harvested by centrifugation at $8000 \mathrm{rpm}$ for $8 \mathrm{~min}$ and the pellet was washed once and re-suspended in Tris-HCl buffer (0.025 M Tris, $0.1 \mathrm{M} \mathrm{NaCl}, \mathrm{pH}$ 8.5). The cells were then incubated in lysis buffer ( $1 \mathrm{mM}$ EDTA, $50 \mu \mathrm{g} \mathrm{mL}{ }^{-1}$ lysozyme, $0.025 \mathrm{M}$ Tris, $0.1 \mathrm{M} \mathrm{NaCl}, \mathrm{pH} 8.5$ ) for $2 \mathrm{~h}$ at $37{ }^{\circ} \mathrm{C}$, and then heated at $75{ }^{\circ} \mathrm{C}$ (PcFn) or $100{ }^{\circ} \mathrm{C}(\mathrm{PFn})$ for $20 \mathrm{~min}$. The preliminarily purified proteins were obtained by collecting the supernatant after centrifugation at $10000 \mathrm{rpm}$ for $30 \mathrm{~min}$ at $4{ }^{\circ} \mathrm{C}$. Further purification was conducted by size exclusion chromatography (Sepharose 6B, GE Healthcare). Finally, purity of the ferritins was analyzed by sodium dodecyl sulfate polyacrylamide gel electrophoresis (SDS-PAGE). The Pierce ${ }^{\mathrm{TM}}$ BCA protein assay kit was used to determine protein concentrations.

\section{Synthesis and transmission electron microscope (TEM) characterization of ferritin cages and magnetoferritins}

The magnetoferritins were synthesized according to the method of our previously studies. ${ }^{36,37}$ All solutions were degassed and transferred into an anaerobic chamber. Taking $\mathrm{M}-\mathrm{PcFn}_{5000}$ for example, the solution of $40 \mathrm{~mL}$ PcFn $\left(1 \mathrm{mg} \mathrm{mL}^{-1}\right)$ in $0.1 \mathrm{M} \mathrm{NaCl}$ was transferred into a reaction vessel, and the reaction temperature was kept at $65{ }^{\circ} \mathrm{C}$ and the $\mathrm{pH}$ was stabilized at 8.5 using $50 \mathrm{mM} \mathrm{NaOH}$ solution with a pH stat titrator. $8.3 \mathrm{~mL}$ of $50 \mathrm{mM}\left(\mathrm{NH}_{4}\right)_{2} \mathrm{Fe}\left(\mathrm{SO}_{4}\right)_{2} \cdot 6 \mathrm{H}_{2} \mathrm{O}$ was added at a rate of $50 \mathrm{Fe} /$ (protein $\mathrm{min}$ ) using a dosing device (800 Dosino). Simultaneously, stoichiometric equivalents $\left(1: 3 \mathrm{H}_{2} \mathrm{O}_{2}: \mathrm{Fe}^{2+}\right)$ of freshly prepared $8.3 \mathrm{~mL} \mathrm{H}_{2} \mathrm{O}_{2}(16.7 \mathrm{mM})$ were added as an oxidant. The magnetite-forming reaction can be expressed as

$$
3 \mathrm{Fe}^{2+}+\mathrm{H}_{2} \mathrm{O}_{2}+2 \mathrm{H}_{2} \mathrm{O} \rightarrow \mathrm{Fe}_{3} \mathrm{O}_{4}+6 \mathrm{H}^{+} .
$$

After adding theoretical 5000 iron atoms per protein cage, $1 \mathrm{~mL}$ of $0.3 \mathrm{M}$ sodium citrate was added to chelate any free iron species. Centrifugation (10 000 $\mathrm{g}$ for $30 \mathrm{~min}$ ) was required to 
remove impurities suspended in the solution. The three of magnetoferritin nanoparticles synthesized were named $\mathbf{M}$ $\mathrm{HFn}_{5000}, \mathrm{M}-\mathrm{PcFn}_{5000}$, and $\mathrm{M}-\mathrm{PFn}_{5000}$. After desalting, $3 \mu \mathrm{L}$ of diluted samples $\left(0.2 \mathrm{mg} \mathrm{mL}^{-1}\right)$ were dropped onto a plasmacleaned carbon-coated copper grid and dried at room temperature overnight. The morphology and crystallography of $\mathrm{M}$ $\mathrm{HFn}_{5000}, \mathrm{M}-\mathrm{PcFn}_{5000}$, and $\mathrm{M}-\mathrm{PFn}_{5000}$ were then analyzed by TEM with an accelerating voltage of $200 \mathrm{kV}$. The size distribution of the three magnetoferritins was measured over 500 particles and crystallographic orientation of the core was examined by highresolution TEM (HR-TEM). For negative-staining TEM observation, apoferritin and magnetoferritin samples $(3 \mu \mathrm{L}, 0.2 \mathrm{mg}$ $\mathrm{mL}^{-1}$ ) were embedded in a Plasma Cleaner HPDC32G treated copper grid and stained with $1 \%$ uranyl acetate for $1 \mathrm{~min}$, then imaged with a JEM-1400 100 kV TEM (JEOL, Japan).

\section{Thermogravimetric analysis (TGA) and ICP Optical Emission Spectrometer (ICP-OES) analysis}

TGA was used to obtain the proportion of ferritin cage of entire magnetoferritin nanoparticles by using TGA/DSC 3 STAR $^{\mathrm{e}}$ thermogravimetric analyzer (Mettler Toledo). The desalted and dried samples were heated from $30{ }^{\circ} \mathrm{C}$ to $700{ }^{\circ} \mathrm{C}$ at $5{ }^{\circ} \mathrm{C} \mathrm{min}{ }^{-1}$ under a $\mathrm{N}_{2}$ flow at $50 \mathrm{~mL} \mathrm{~min}^{-1}$. $\mathrm{N}_{2}$ flow is used to prevent the further oxidation of $\mathrm{Fe}_{3} \mathrm{O}_{4}$. ICP-OES (Avio 200 ICP Optical Emission Spectrometer, PerkinElmer) was used to determine the iron content of magnetoferritins. The iron standard sample was diluted into $0 \mathrm{ppm}, 20 \mathrm{ppm}, 40 \mathrm{ppm}, 60 \mathrm{ppm}, 80 \mathrm{ppm}$ and $100 \mathrm{ppm}$, and the samples were dissolved by $5 \%$ (v/v \%) hydrochloric acid and prepared with the concentration lower than 100 ppm before measured.

\section{Magnetic measurements of magnetoferritins}

Magnetic measurements were conducted with a Magnetic Property Measurement System (MPMS-5XL, Quantum Design,

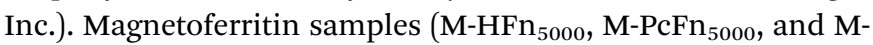
$\mathrm{PFn}_{5000}$ ) were desalted and dried before magnetic measurements were taken. The isothermal remanent magnetization (IRM) acquisition and demagnetization remanence (DCD) curves were measured at $5 \mathrm{~K}$ within $\pm 1000 \mathrm{mT}$ for calculation of magnetostatic interactions. Hysteresis loops were measured in field range of $-3 \mathrm{~T}$ to $3 \mathrm{~T}$ at $5 \mathrm{~K}$ and $300 \mathrm{~K}$, respectively.

\section{Temperature gradient treatment of the ferritin cages and magnetoferritins}

All samples ( $1 \mathrm{~mL}$ of a $0.5 \mathrm{mg} \mathrm{mL}^{-1}$ solution in $0.1 \mathrm{M} \mathrm{NaCl}, \mathrm{pH}$ 8.5) were prepared in $1.5 \mathrm{~mL}$ centrifuge tubes and heated for

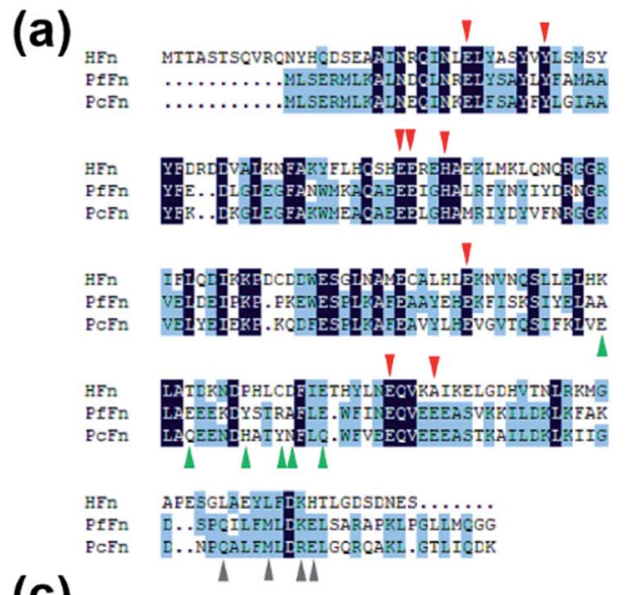

(c)

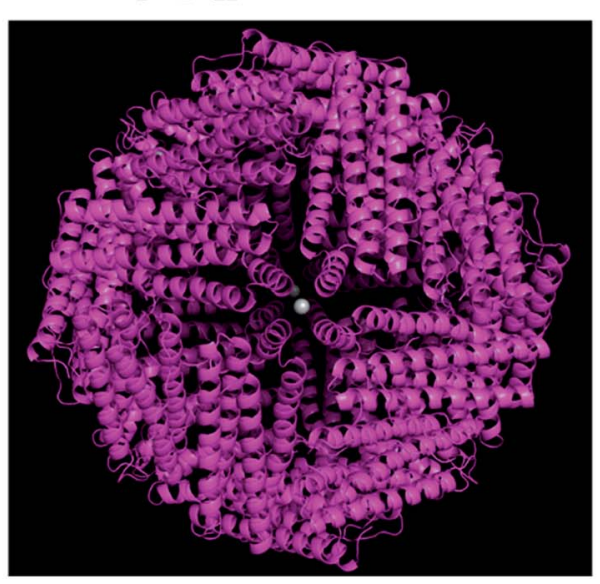

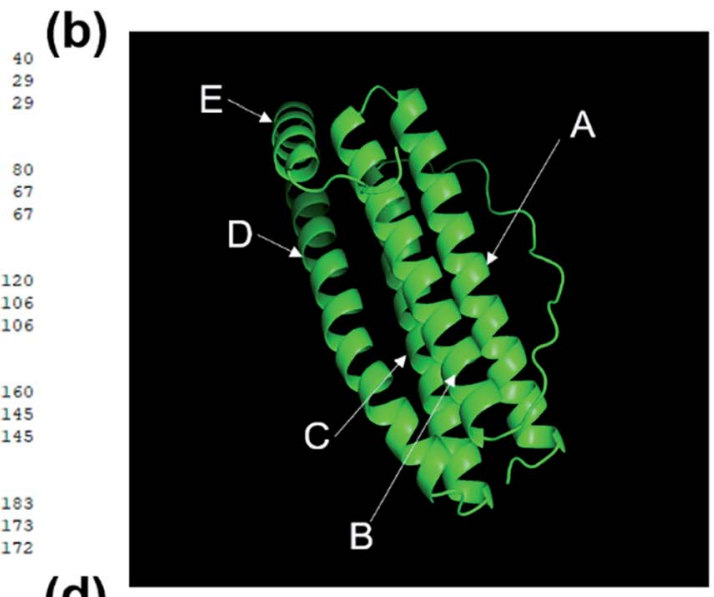

(d)

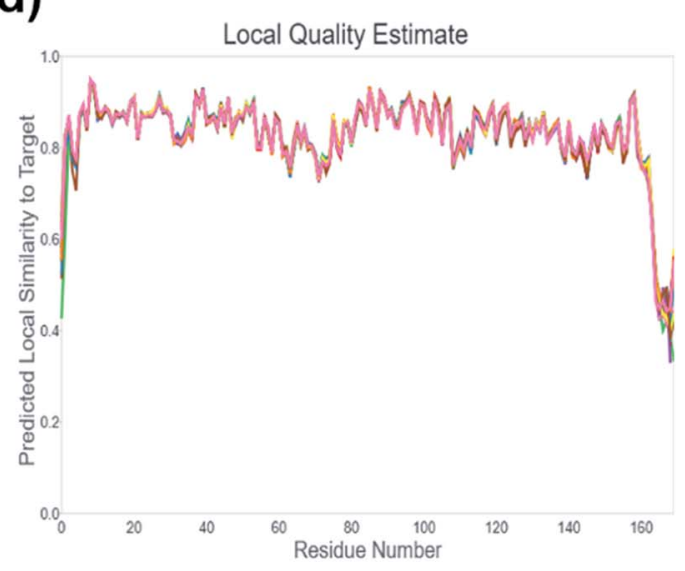

Fig. 1 Amino acid sequence analysis and protein structure prediction. (a) Amino acid sequence analysis of HFn, PfFn and PcFn. The red triangle shows the ferroxidase sites, the green triangle shows the threefold channels sites, and the gray triangle shows the fourfold channel sites. (b) The predicted subunit of PcFn with five $\alpha$-helix: A, B, C, D and E. (c) The predicted 24-mer of PcFn templated by ferritin (PDB ID: 2X17). (d) The local quality estimate of predicted model. 
$30 \mathrm{~min}$ in a heat block (at $70{ }^{\circ} \mathrm{C}, 80{ }^{\circ} \mathrm{C}, 90{ }^{\circ} \mathrm{C}$, and $100{ }^{\circ} \mathrm{C}$ ) or oil bath $\left(110{ }^{\circ} \mathrm{C}\right.$ and $\left.120{ }^{\circ} \mathrm{C}\right)$ with a temperature gradient. The centrifuge tubes were wrapped with sealing film to prevent evaporation. After heating, all samples were centrifuged (14500 rpm) for $10 \mathrm{~min}$ and stabilized at $4{ }^{\circ} \mathrm{C}$ overnight.

(a)

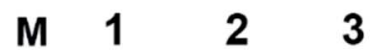

(b)

M

12

3

kDa

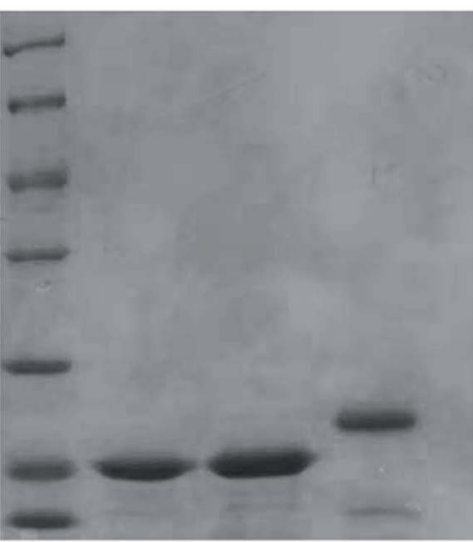

kDa

669

45.0

35.0

25.0

18.4

14.4

232
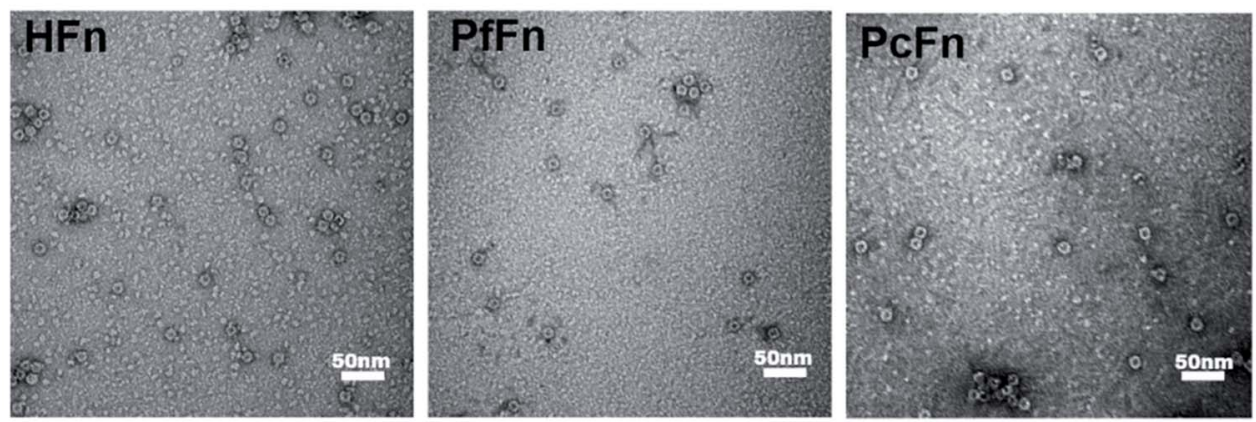

(d)

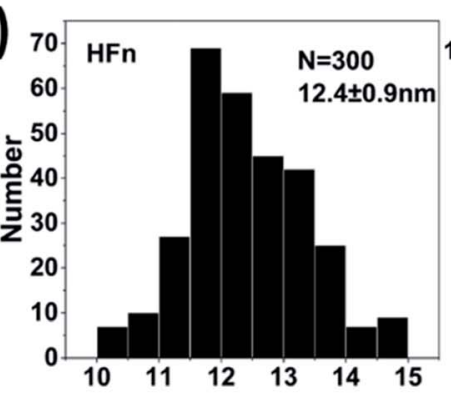

(e)
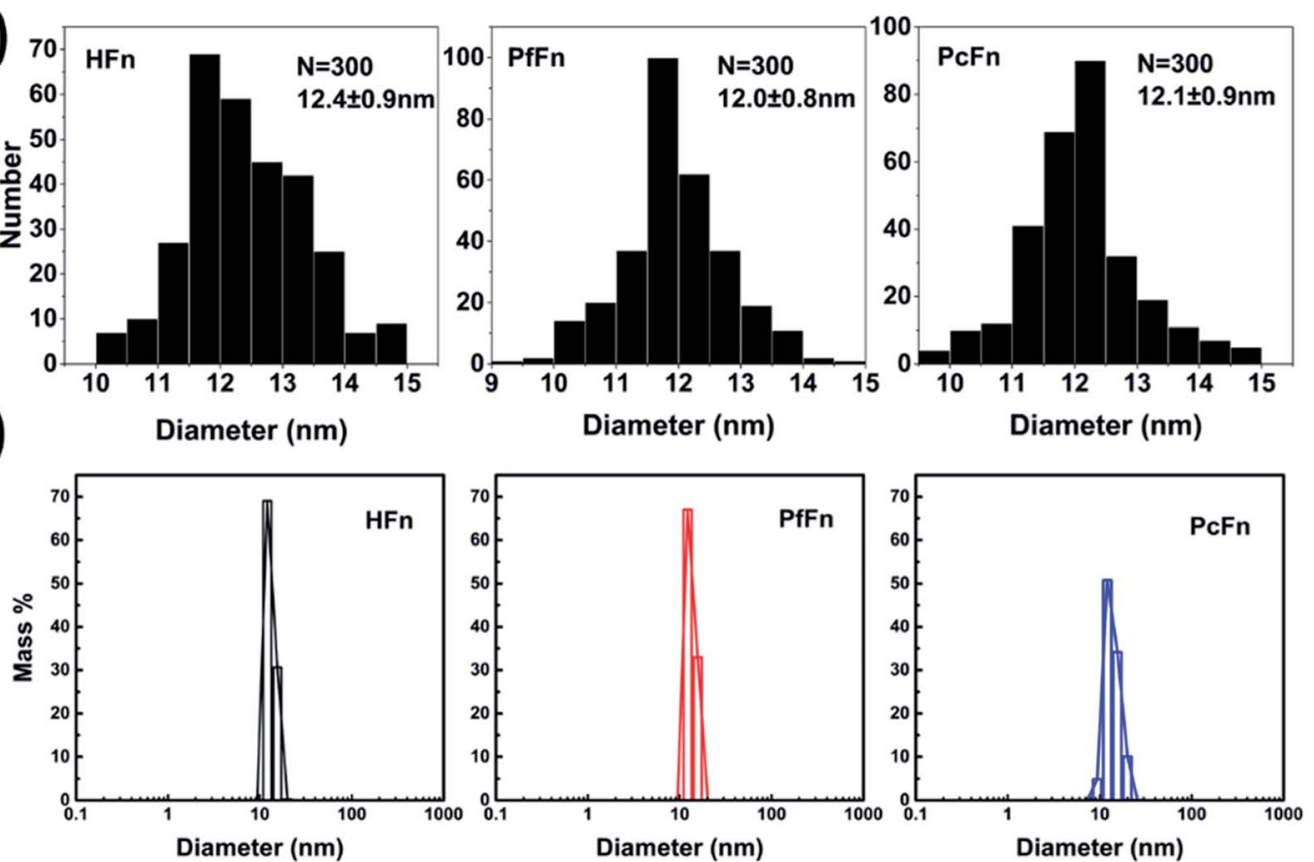

Fig. 2 Characteristics of recombinant ferritin cages. (a) SDS-PAGE and (b) native-PAGE analyses of recombinant ferritins. Lane M: protein markers and their corresponding molecular masses, lane 1: PcFn, lane 2: PfFn, lane 3: HFn. (c) Negative-stained TEM images of ferritin cages, scale bar is $50 \mathrm{~nm}$. (d) Histograms of size distributions of ferritin cages. (e) DLS analysis of HFn, PfFn, and PcFn nanocages, with diameters in solution of $12.1,13.3$, and $13.9 \mathrm{~nm}$, respectively. 
$\mathrm{M}-\mathrm{HFn}_{5000}$ protein cage

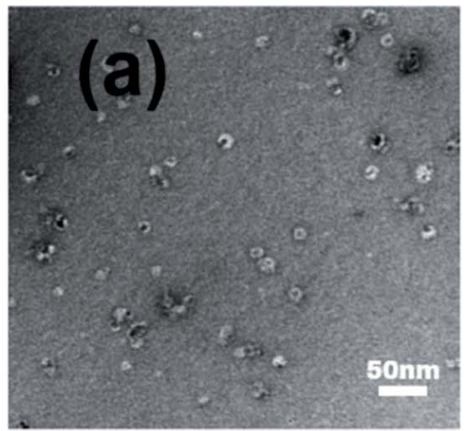

$\mathrm{M}-\mathrm{PfFn}_{5000}$ protein cage

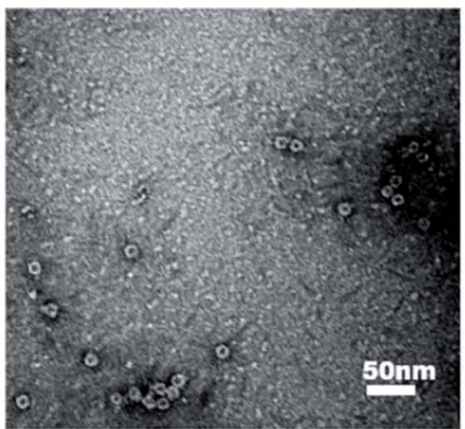

$\mathrm{M}-\mathrm{PcFn}_{5000}$ protein cage
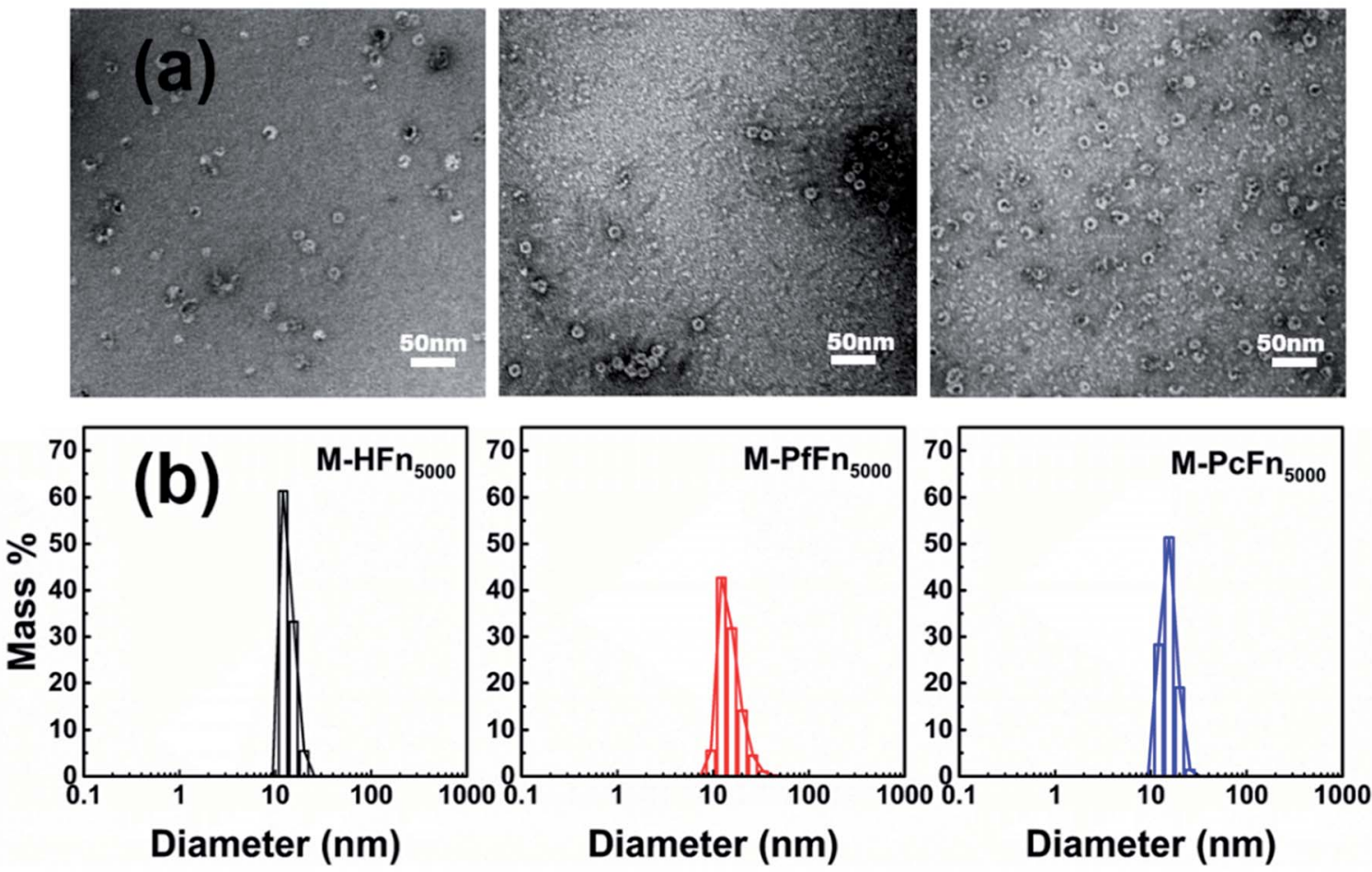

$\mathrm{M}-\mathrm{HFn}_{5000}$ core

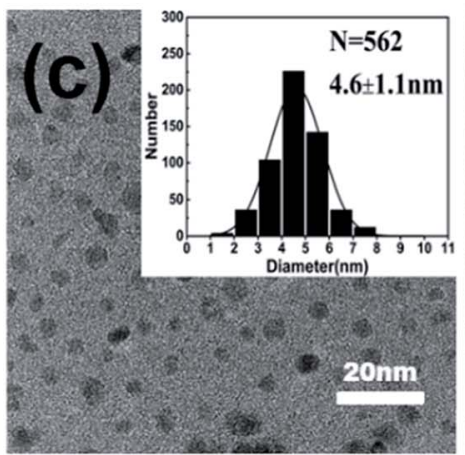

$\mathrm{M}-\mathrm{HFn}{ }_{5000}$ core

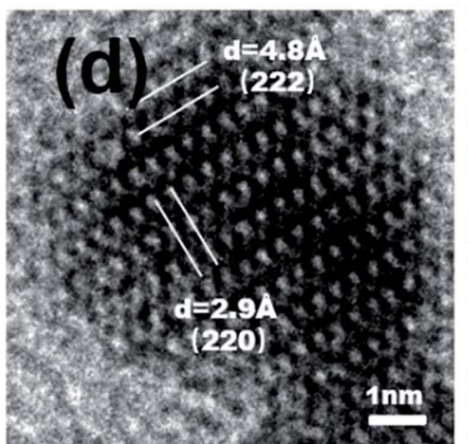

$\mathrm{M}-\mathrm{PfFn}_{5000}$ core

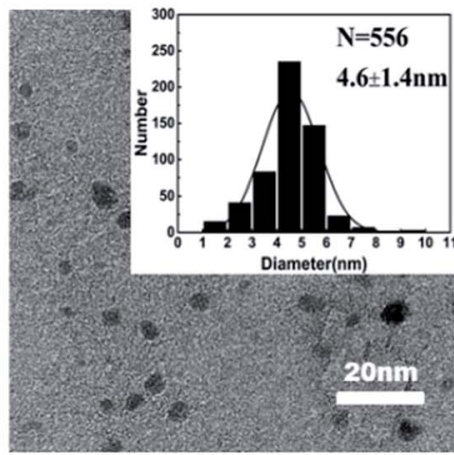

$\mathrm{M}-\mathrm{PfFn}_{5000}$ core
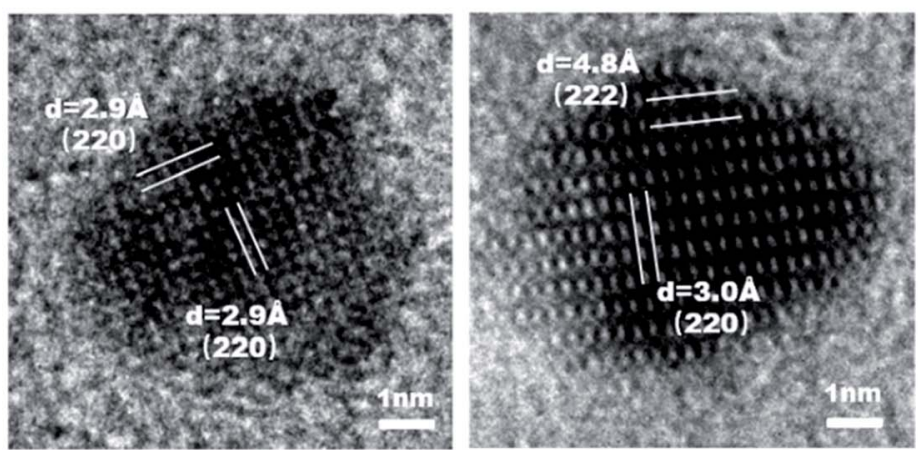

Fig. 3 Characteristics of magnetoferritins. (a) TEM images of negative-stained magnetoferritins $\left(M-H F n_{5000}, M-P f F n_{5000}\right.$, and M-PcFn bar is $50 \mathrm{~nm}$. (b) DLS analysis of native $\mathrm{M}-\mathrm{HFn}_{5000}, \mathrm{M}-\mathrm{PfFn}_{5000}, \mathrm{M}-\mathrm{PcFn}_{5000}$ nanocages, with diameters in solution of 13.6, 15.3, 15.5 nm, respectively. (c) TEM images of M-HFn5000, M-PfFn5000, and M-PcFn5000 nanoparticles, and histograms of size distributions of magnetoferritins. Scale bar is $20 \mathrm{~nm}$. (d) High-resolution TEM images showing lattice fringes of the magnetite cores. Scale bar is $1 \mathrm{~nm}$. 
Dynamic light scattering (DLS) analysis of ferritin cages and magnetoferritins

The hydrodynamic size of apoferritins and magnetoferritins were determined by dynamic light scattering (DLS) (DynaPro NanoStar, Wyatt Technology Corporation. USA) at $25{ }^{\circ} \mathrm{C}$ with a scattering angle of $90{ }^{\circ} \mathrm{C}$. Diluted samples $\left(0.5 \mathrm{mg} \mathrm{mL}^{-1}\right.$ in $0.1 \mathrm{M} \mathrm{NaCl}$ solution) were filtered with a $0.22 \mu \mathrm{m}$ filter membrane and $10 \mu \mathrm{L}$ of sample was used for DLS measurements.

\section{Circular dichroism (CD) measurements of ferritin cages and magnetoferritins}

CD spectra were taken on a Chirascan ${ }^{\mathrm{TM}}$-Plus CD spectrometer (Applied Photophysics, Leatherhead, UK) at 200-260 nm (bandwidth: $1 \mathrm{~nm}$ ) at protein concentrations $\sim 0.1 \mathrm{mg} \mathrm{mL}^{-1}$. An attached software CDNN was used to calculate the secondary structure content and composition of all data by autodeconvolution.

\section{Differential scanning calorimetry (DSC) analysis}

DSC was performed in a Nano DSC Microcalorimeter (TA instruments, Waters LLC, USA). Before DSC measurements were taken, $1 \mathrm{mg} \mathrm{mL}^{-1}$ of each sample in $0.1 \mathrm{M} \mathrm{NaCl}(\mathrm{pH} 8.5)$ was filtered through a $0.22 \mu \mathrm{m}$ filter, degassed for $15 \mathrm{~min}$, and loaded into the Nano DSC. The experiments were carried out under pressure of $303 \mathrm{kPa}$ to avoid degassing during heating. The protein was heated in the Nano DSC at a scan rate of $1{ }^{\circ} \mathrm{C} \mathrm{min}{ }^{-1}$ over a range of 60 to $130^{\circ} \mathrm{C}$. After buffer subtraction and concentration normalization, a plot of excess heat capacity versus temperature was obtained, and baseline was determined by manually adjusting the left and right linear line segments. Each peak was then set to the median temperature $\left(T_{\mathrm{m}}\right)$, the curve was fit with a non-two-state model, and the calorimetric enthalpy $(\Delta H)$ was calculated as the integral of the fitting curve area.

\section{Iron uptake assay of recombinant ferritins}

Iron incorporation experiment was conducted at $25{ }^{\circ} \mathrm{C}$ and monitored spectrophotometrically at $315 \mathrm{~nm}$ for $20 \mathrm{~min}$. Specifically, $10 \mathrm{mM}$ ammonium ferrous sulfate solution with $4.95 \mathrm{mg} \mathrm{mL}^{-1}$ thiourea was prepared as $\mathrm{Fe}^{2+}$ reagent and prevented the autoxidation of $\mathrm{Fe}^{2+}$. HEPES $(0.1 \mathrm{M}, \mathrm{pH} 7.0)$ was prepared as reaction buffer. After adding ferritins to HEPES reaction buffer at a final concentration of $0.025 \mathrm{mg} \mathrm{mL}^{-1}, 20 \mu \mathrm{L}$ $\mathrm{Fe}^{2+}$ reagent was rapidly mixed and scanned in a UV/visible spectrophotometer.

\section{Results and discussion}

\section{Sequence alignment and structure analysis}

Fig. 1a shows the comparison of amino acid sequence of PcFn with HFn (36\% identity, 55\% similarity, 10\% gaps) and PfFn ( $63 \%$ identity, $80 \%$ similarity, $0 \%$ gaps). The ferroxidase center of these three ferritins are highlighted in red triangle. Similar to PfFn, the residues E17, Y24, E50, and $\mathrm{H} 53$ of PcFn are characterized as motif EXXH, and Q127 and E130 arranged as the motif QXXE, ${ }^{28}$ which are highly conserved. The threefold channels sites of PcFn: E106, Q109, H114, Y117, N118, and Q121 are totally different from that of PfFn and HFn (shown in green triangle). However, the fourfold channels sites of PcFn: Q149, M153, R156, E157 are identical to that of PfFn (gray triangle), ${ }^{29}$ but different from HFn. In addition, the tertiary structure and quaternary structure of PcFn were predicted by using a template ferritin (PDB ID: 2X17) on the website (https:// swissmodel.expasy.org). The subunit structure of PcFn is similar to HFn (PDB ID: 2FHA) and PfFn (PDB ID: 2X17), which is composed of five $\alpha$-helix: A, B, C, D, and E (Fig. 1b). The predicted quaternary structure of PcFn is also cage-like protein with 24 subunits and consistent with the HFn and PfFn (Fig. 1c).

\section{Synthesis and characteristics of recombinant ferritin cages}

The recombinant ferritins (HFn, PfFn, and PcFn) were overexpressed in E. coli BL21 cells. After purification, the proteins were analyzed by SDS-PAGE and native PAGE. According to the amino acid sequence, the predicted molecular weights (MW) of HFn, PfFn and PcFn subunit are 21.2 kDa, 20.3 kDa, $20.1 \mathrm{kDa}$, respectively. The MW of the native HFn, PfFn, and PcFn subunits in the SDS-PAGE result were determined to be $\sim 20$ $\mathrm{kDa}, \sim 19 \mathrm{kDa}$, and $\sim 19 \mathrm{kDa}$, with only one protein band observed for each, indicating high purity of each protein (Fig. 2a). In the native PAGE gel, we can see that all three proteins had an apparent band at approximately $440 \mathrm{kDa}$, suggesting that the full protein PcFn may be composed of 24 subunits (Fig. 2b), which is accordant with the predict structure in Fig. 1c. To further investigate the size and protein architecture of PcFn, TEM and DLS were performed. Bright-field TEM images of negative stained apo-ferritins (Fig. 2c) showed that all the protein cages were monodispersed and intact, and the outer diameter of HFn, PfFn, and PcFn is $12.4 \pm 0.9 \mathrm{~nm}, 12.0 \pm$ $0.8 \mathrm{~nm}$ and $12.1 \pm 0.9 \mathrm{~nm}$, respectively (Fig. 2d). DLS results confirmed that the native HFn, PfFn, and PcFn protein cages were monodispersed, with average outer diameters of 12.1, 13.3, and $13.9 \mathrm{~nm}$ in solution (0.1 M NaCl), respectively (Fig. 2e), which is accordance with the TEM results and previously reported ferritin sizes. ${ }^{38}$

\section{Synthesis and characteristics of magnetoferritins}

The magnetoferritins ( $\mathrm{M}-\mathrm{HFn}_{5000}, \mathrm{M}-\mathrm{PfFn}_{5000}$, and $\left.\mathrm{M}-\mathrm{PcFn}_{5000}\right)$ were synthesized by step-wise loading of iron oxide nanoparticles into the HFn, PfFn, and PcFn nanocages. After synthesis and purification by centrifugation and size exclusion

Table 1 Ferritin cage and iron content of synthesized M-HFn $n_{5000}, \mathrm{M}$ $\mathrm{PfFn}_{5000}$, and $\mathrm{MPCFn}_{5000}$

\begin{tabular}{llll}
\hline Sample & $\begin{array}{l}\text { Ferritin cage } \\
(\text { wt\%) }\end{array}$ & $\begin{array}{l}\text { Fe } \\
\text { (wt\%) }\end{array}$ & $\begin{array}{l}\text { Number } \\
\text { (Fe atom/ferritin cage) }\end{array}$ \\
\hline $\mathrm{M}-\mathrm{HFn}_{5000}$ & 42.6 & 19.9 & 4244 \\
$\mathrm{M}-\mathrm{PfFn}_{5000}$ & 47.8 & 28.6 & 4132 \\
$\mathrm{M}-\mathrm{PcFn}_{5000}$ & 56.9 & 22.7 & 4330
\end{tabular}


Table 2 Magnetic parameters of magnetoferritins ${ }^{a}$

\begin{tabular}{|c|c|c|c|c|c|c|c|}
\hline Samples & $\begin{array}{l}\text { Mean size } \\
(\mathrm{nm})\end{array}$ & $\begin{array}{l}M_{\mathrm{rs}}(5 \mathrm{~K}) \\
\left(\mathrm{emu} \mathrm{g}^{-1}\right)\end{array}$ & $\begin{array}{l}M_{\mathrm{S}}(5 \mathrm{~K}) \\
\left(\mathrm{emu} \mathrm{g}^{-1}\right)\end{array}$ & $\begin{array}{l}M_{\mathrm{rs}} / M_{\mathrm{s}} \\
(5 \mathrm{~K})\end{array}$ & $\begin{array}{l}H_{\mathrm{c}}(5 \mathrm{~K}) \\
(\mathrm{mT})\end{array}$ & $\begin{array}{l}M_{\mathrm{s}}(300 \mathrm{~K}) \\
\left(\mathrm{emu} \mathrm{g}^{-1}\right)\end{array}$ & $R$ \\
\hline $\mathrm{M}-\mathrm{HFn}_{5000}$ & 4.6 & 8.7 & 26.7 & 0.33 & 28.9 & 21.3 & 0.42 \\
\hline $\mathrm{M}-\mathrm{PfFn}_{5000}$ & 4.6 & 6.9 & 21.5 & 0.32 & 23.1 & 17.2 & 0.44 \\
\hline $\mathrm{M}-\mathrm{PfFn}_{5000}-110^{\circ} \mathrm{C}$ & 4.6 & 8.5 & 35.9 & 0.24 & 14.7 & 28.1 & 0.43 \\
\hline $\mathrm{M}-\mathrm{PcFn}_{5000}$ & 4.7 & 8.8 & 24.1 & 0.37 & 27.8 & 19.3 & 0.43 \\
\hline
\end{tabular}

${ }^{a} M_{\mathrm{rs}}$, saturation remanence; $M_{\mathrm{s}}$, saturation magnetization; $H_{\mathrm{c}}$, coercivity; $R$ value was determined by Wohlfarth-Cisowski test, as shown in Fig. S2. $R$ value of 0.5 suggesting no magnetostatic interaction.

chromatography, the protein cages could be seen clearly in negative-stained TEM images, indicating no disruption of the protein cages during synthesis (Fig. 3a). DLS data for the magnetoferritins shows hydrodynamic diameters (HD) of 13.6, 15.3, and $15.5 \mathrm{~nm}$ for $\mathrm{M}-\mathrm{HFn}_{5000}, \mathrm{M}-\mathrm{PfFn}_{5000}$, and $\mathrm{M}-\mathrm{PcFn}_{5000}$ (Fig. 3b), respectively, which were only slightly larger than the original protein cages. This also confirms that the iron oxide nanoparticles were encapsulated by protein cages, because the
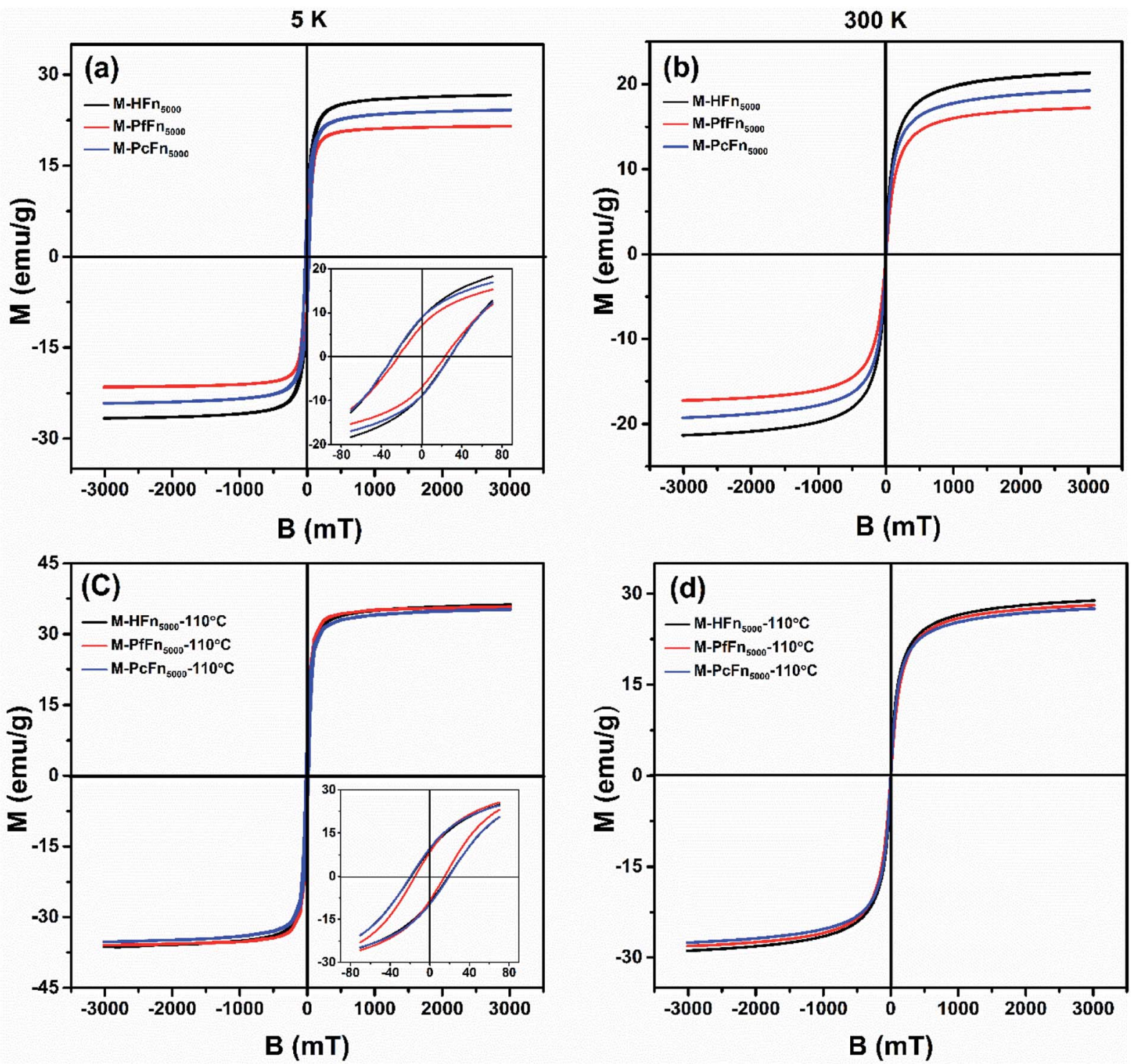

Fig. 4 Hysteresis loops of the desalted and dried magnetoferritins before and after heating at $110^{\circ} \mathrm{C}$ for 30 min measured at $5 \mathrm{~K}(\mathrm{a}$ and $\mathrm{c}$ ) and 300 $K(b$ and $d)$. 
aggregation of iron oxide nanoparticles always causes little changes in HD. TEM images show all the synthesized cores of magnetoferritins are monodispersed and sphere-like nanoparticles with mean diameters of $4.6 \pm 1.1 \mathrm{~nm}, 4.6 \pm 1.4 \mathrm{~nm}$, and $4.7 \pm 1.3 \mathrm{~nm}$ for $\mathrm{M}-\mathrm{HFn}_{5000}, \mathrm{M}-\mathrm{PfFn}_{5000}$, and $\mathrm{M}-\mathrm{PcFn}_{5000}$, respectively (Fig. 3c). The size of $\mathbf{M}-\mathrm{HFn}_{5000}$ is in accordance with previously published data, ${ }^{36,39}$ while the size distributions of $\mathrm{M}-\mathrm{PfFn}_{5000}$ and $\mathrm{M}-\mathrm{PcFn}_{5000}$ are slightly broader than for M$\mathrm{HFn}_{5000}$. High-resolution TEM images (Fig. 3d) indicate that the cores of all three magnetoferritins are well-crystalline with clear lattice fringes. The measured lattice planes (220), (222) indicate that the mineral structure is magnetite $\left(\mathrm{Fe}_{3} \mathrm{O}_{4}\right)$ or maghemite $\left(\gamma-\mathrm{Fe}_{2} \mathrm{O}_{3}\right)$. Despite the fact that PcFn shares only $36 \%$ aminoacid sequence identity with HFn, and 63\% identity with PfFn, the protein cages are very similar in shape and size. All of these ferritins can be used as good templates for controlled synthesis of magnetic nanoparticles with uniform shape and size distributions. In addition, these protein shells can greatly improve their dispersibility and help maintain lower magnetic interactions of the inner magnetite cores.

In order to determine the ferritin cage and iron content of magnetoferritins, TGA combined with ICP-OES was conducted. TGA results indicate that organic content (ferritin cage) of $\mathrm{M}$ $\mathrm{HFn}_{5000}, \mathrm{M}-\mathrm{PfFn}_{5000}$, and $\mathrm{M}-\mathrm{PcFn}_{5000}$ were $42.6 \%, 47.8 \%$, and $56.9 \%$ (Fig. S1 $\dagger$ ), and $\mathrm{Fe} \%$ of these particles measured ICP-MOS are listed in Table 1. According to the data, we calculated that each ferritin cage of $\mathrm{M}-\mathrm{HFn} \mathbf{n}_{5000}, \mathrm{M}-\mathrm{PfFn}_{5000}$, and $\mathrm{M}-\mathrm{PcFn}_{5000}$ contain 4244, 4330, and 4132 Fe atoms, respectively. The iron atoms number inside protein cages are lower than theoretical 5000 iron atoms per protein cage and the loss of iron may be due to aggregation of Fe outside the ferritin cage, which were chelated by citrate and removed by centrifugation after reaction.

\section{Magnetic properties of magnetoferritin nanoparticles}

The magnetic properties of magnetoferritins (before and after heating at $110{ }^{\circ} \mathrm{C}$ for $30 \mathrm{~min}$ ) were measured and summarized in Table 2 and Fig. 4 . The $5 \mathrm{~K}$ coercivity $\left(H_{\mathrm{c}}\right)$ of $\mathrm{M}-\mathrm{HFn}_{5000}, \mathrm{M}$ $\mathrm{PfFn}_{5000}$, and M-PcFn 5000 were $28.9 \mathrm{mT}, 23.1 \mathrm{mT}$, and $27.8 \mathrm{mT}$, respectively, which are in agreement with the coercivity of magnetite or maghemite among $20-30 \mathrm{mT}$. ${ }^{40}$ At $5 \mathrm{~K}$, the shape of the hysteresis loops among these samples are slightly constricted (wasp-waisted), meaning that some ultrasmall iron oxide nanoparticles are not unblocking at $5 \mathrm{~K}$, and superparamagnetic and single-domain magnetite nanoparticles coexist in the samples. The ratios of saturation remanence to saturation magnetization $\left(M_{\mathrm{rs}} / M_{\mathrm{s}}\right)$ at $5 \mathrm{~K}$ were $0.32,0.35$, and 0.37 for $\mathrm{M}-\mathrm{HFn}_{5000}, \mathrm{M}-\mathrm{PfFn}_{5000}$, and $\mathrm{M}-\mathrm{PcFn}_{5000}$, respectively, indicating that all these samples are dominated by uniaxial anisotropy. ${ }^{41}$ Based on the Wohlfarth-Cisowski test for randomly oriented noninteracting single-domain (SD) particles, the isothermal remanent magnetization acquisition curve (IRM) and direct current demagnetization curve (DCD) $\operatorname{cross} R=0.5{ }^{42}$ In this study, the $R$ values of $\mathrm{M}-\mathrm{HFn}_{5000}, \mathrm{M}-\mathrm{PfFn}_{5000}$, and $\mathrm{M}$ $\mathrm{PcFn}_{5000}$ were $0.42,0.44$, and 0.43 , respectively, indicating very weak magnetic interactions in all these samples, likely because the magnetite nanoparticles were well-dispersed by protein
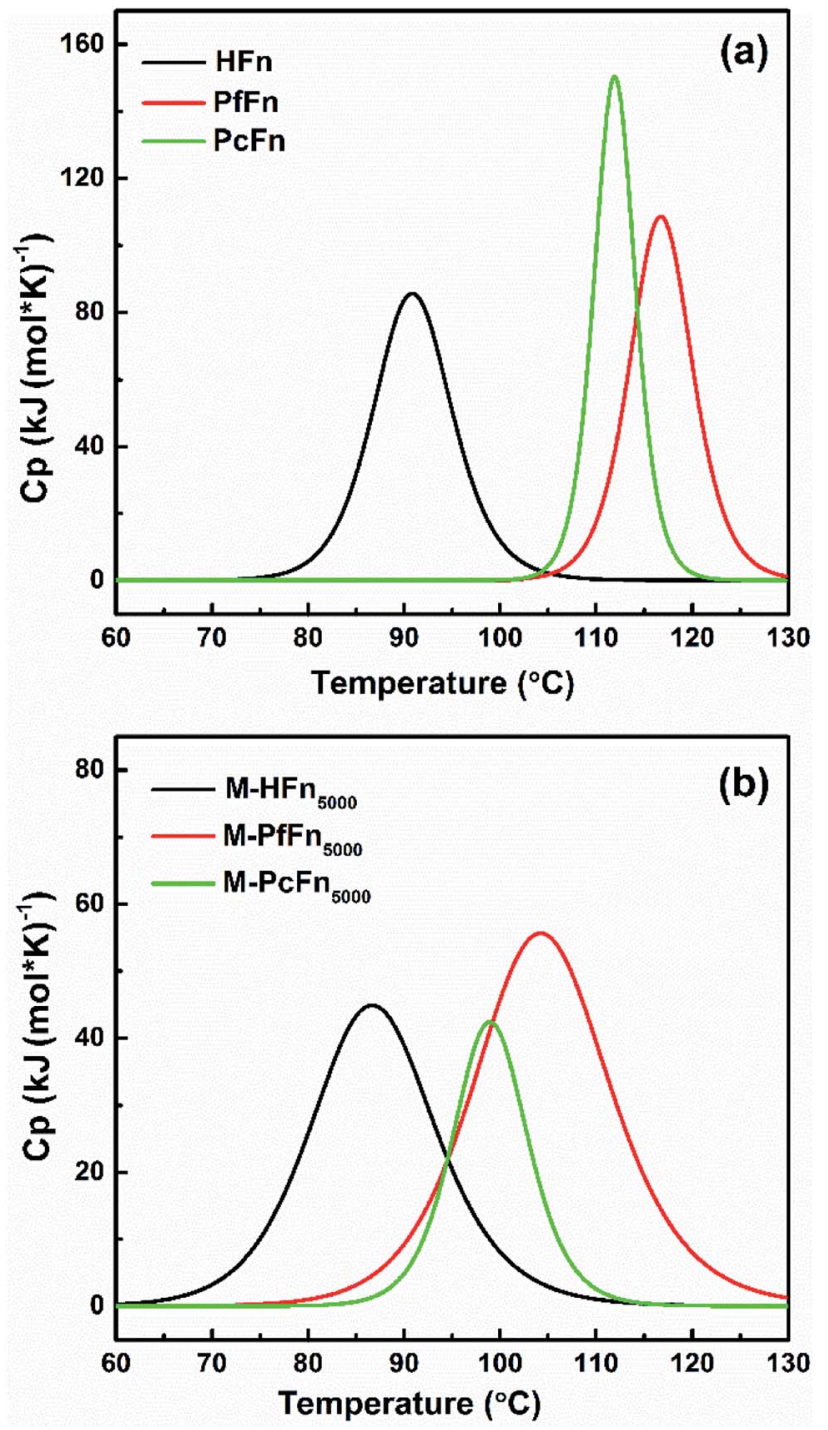

Fig. 5 DSC profiles of ferritins (HFn, PfFn, and PcFn) and magnetoferritins $\left(\mathrm{M}-\mathrm{HFn_{5000 }}, \mathrm{M}-\mathrm{PfFn}_{5000}\right.$, and $\left.\mathrm{M}-\mathrm{PCFn}_{5000}\right)$. Measurements were carried out in $0.1 \mathrm{M} \mathrm{NaCl}$ at pH 8.5. The scan rate was $1^{\circ} \mathrm{C} \mathrm{min}$.

cages (Table 2 and Fig. S2 $\dagger$ ). At $300 \mathrm{~K}$, these three particle types showed no $M_{\mathrm{rs}}$ (Fig. 4b). Moreover, after heating at $110{ }^{\circ} \mathrm{C}$, the value of $M_{\mathrm{rs}}, M_{\mathrm{s}}$ at $5 \mathrm{~K}$ and $M_{\mathrm{s}}$ at $300 \mathrm{~K}$ increases but the value of $H_{\mathrm{c}}$ decreases, which could be explained by that some surface atoms rearranged to align dominant axial orientation after

Table 3 Thermodynamic parameters for thermal denaturation of ferritin cages and magnetoferritins

\begin{tabular}{lrl}
\hline Sample $\left(1 \mathrm{mg} \mathrm{mL}^{-1}\right)$ & $T_{\mathrm{m}}\left({ }^{\circ} \mathrm{C}\right)$ & $\Delta H\left(\mathrm{~kJ} \mathrm{~mol}^{-1}\right)$ \\
\hline HFn & 90.9 & 402.8 \\
PFn & 116.8 & 580.1 \\
PcFn & 112.0 & 861.0 \\
M-HFn & 86.9 & 248.4 \\
M-PFn & 104.5 & 250.5 \\
M-PcFn & 100.1 & 441.9
\end{tabular}


heating and reduced the surface spin disorder thickness of the magnetoferritin core. The $R$ value of each sample is nearly the same after heating at $110{ }^{\circ} \mathrm{C}$, indicating weak magnetic interaction among each magnetic nanoparticle and no disruption of ferritin cages under high temperature.

\section{Thermostability of recombinant ferritins}

The protein concentration of each sample heated at different temperatures $\left(25^{\circ} \mathrm{C}, 70^{\circ} \mathrm{C}, 80^{\circ} \mathrm{C}, 90^{\circ} \mathrm{C}, 100^{\circ} \mathrm{C}, 110^{\circ} \mathrm{C}\right.$, and 120 $\left.{ }^{\circ} \mathrm{C}\right)$ for 30 min was determined by BSA method after centrifugation (14 $500 \mathrm{rpm}$ ) for $10 \mathrm{~min}$ and stabilized at $4{ }^{\circ} \mathrm{C}$ overnight. It was clear that the concentration of HFn decreased when the heating temperature reached $90{ }^{\circ} \mathrm{C}$. When the heating temperature was increased to $110^{\circ} \mathrm{C}$, only $18.7 \%$ of the original protein was preserved, while most of the HFn aggregated and precipitated (Fig. S3 $\dagger$ ). In contrast, most of the PfFn and PcFn were still soluble when the temperature reached $110{ }^{\circ} \mathrm{C}$, and maintained $78.3 \%$ and $76.2 \%$ of the protein concentration, respectively.

DSC is a technology that can characterize protein stability by measuring the thermal denaturation of samples while heating at a constant rate. The excess heat capacity $\left(C_{\mathrm{p}}\right)$ temperature curves and fitting curves are shown in Fig. 5. $T_{\mathrm{m}}$ value and the calorimetric enthalpy $(\Delta H)$ were acquired according to the fitting curve. It is shown that the $T_{\mathrm{m}}$ values for HFn, PfFn, and PcFn were $90.9^{\circ} \mathrm{C}, 116.8^{\circ} \mathrm{C}$ and $112.0{ }^{\circ} \mathrm{C}$, respectively. The $T_{\mathrm{m}}$ values for PfFn and PcFn were significantly higher than for HFn, reflecting that the structures of PcFn and PfFn in solution are more stable than that of HFn (Table 3). The $\Delta H$ values of HFn, PfFn, and PcFn were 402.8, 580.1, 861.0 $\mathrm{kJ} \mathrm{mol}^{-1}$, respectively. The differences in $\Delta H$ values are probably related to the different processes of protein unfolding during heating. It should be noted that a previous study reported the DSC results of PfFn with no $T_{\mathrm{m}}$ from $20{ }^{\circ} \mathrm{C}$ to $120^{\circ} \mathrm{C},{ }^{28}$ which is different from our results of a $T_{\mathrm{m}}$ for PfFn of $116.8^{\circ} \mathrm{C}$. There might be two explanations for this: (1) ferritin has been demonstrated to be relatively thermolabile at high protein concentrations, ${ }^{43}$ and the DSC experiments were performed at a relatively higher concentration of PfFn in this study $\left(1 \mathrm{mg} \mathrm{mL}^{-1}\right)$ than that of previous study $\left(\sim 0.15 \mathrm{mg} \mathrm{mL}^{-1}\right)$; (2) we used $0.1 \mathrm{M} \mathrm{NaCl}$ to stabilize the ferritins which has a lower ionic strength than the buffer of PfFn previously used (50 mM HEPES, $250 \mathrm{mM} \mathrm{NaCl}$ solution, $\mathrm{pH} 7$ or $1 \times$ PBS solution, $\mathrm{pH}$ 7.4).

To analyze heat-induced structural changes in the $\alpha$-helical structure of ferritin, CD spectra were performed at protein concentrations of $0.1 \mathrm{mg} \mathrm{mL} \mathrm{m}^{-1}$. As shown in Fig. 6a-c, the curves of HFn obviously shift upward with increased temperature. However, the curves of PcFn and PfFn began to shift until the heating temperature reached $120{ }^{\circ} \mathrm{C}$. To quantify the proportion of secondary structure in the samples, the original data was imported into a software CDNN to calculate the $\alpha$ helical, $\beta$-sheet, and random coil contents. The $\alpha$-helical content of HFn, PcFn, and PfFn heated to $110{ }^{\circ} \mathrm{C}$ decreased by
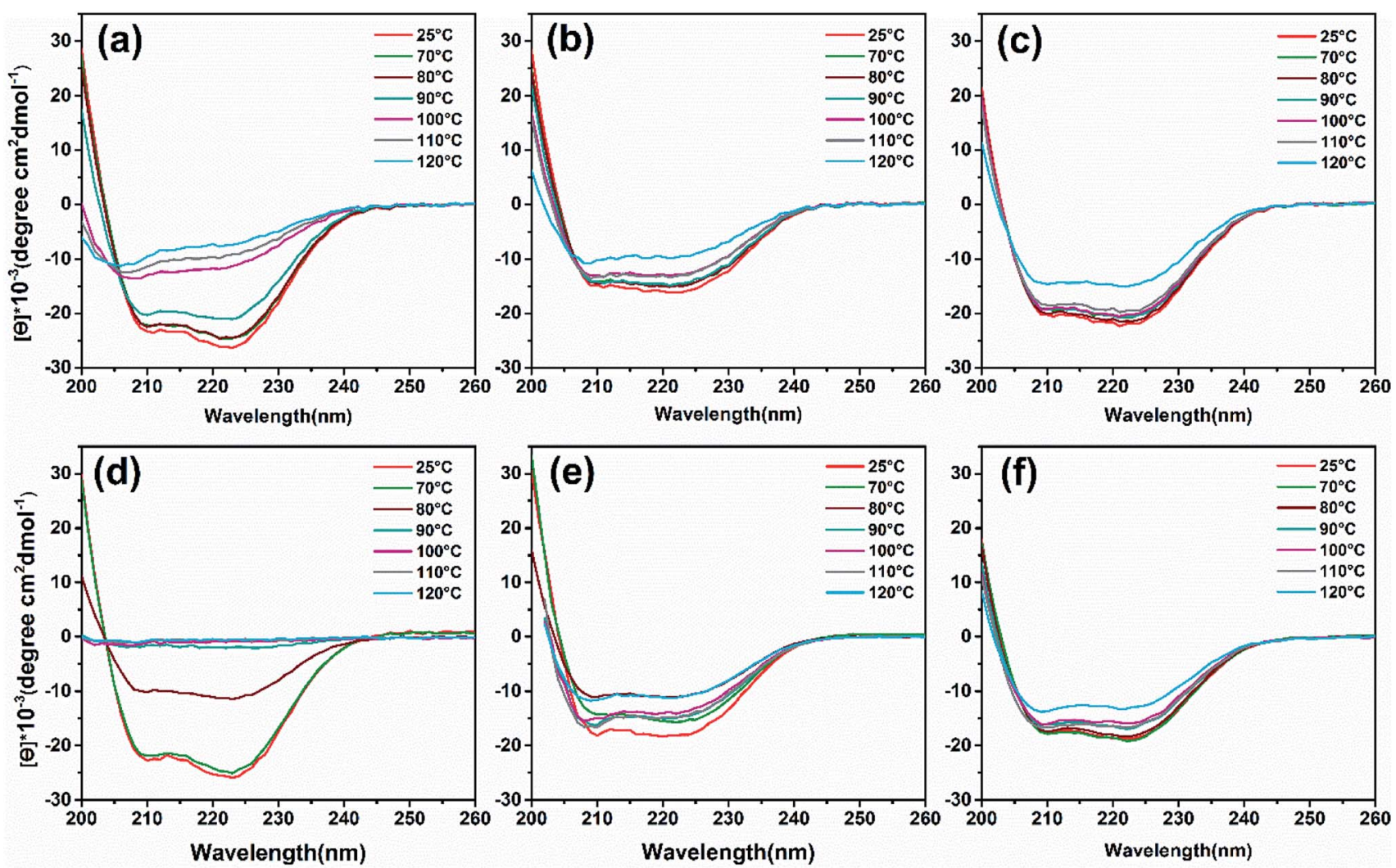

Fig. $6 \mathrm{CD}$ wavelength scans of ferritins and magnetoferritins with temperature gradient treated (control group, $70^{\circ} \mathrm{C}, 80^{\circ} \mathrm{C}, 90^{\circ} \mathrm{C}, 100{ }^{\circ} \mathrm{C}$, $110^{\circ} \mathrm{C}, 120^{\circ} \mathrm{C}$ ) and composition of $\alpha$-helix. (a) HFn, (b) PfFn, (c) PcFn. (d) M-HFn5000, (e) M-PfFn5000, (f) M-PcFn5000. 

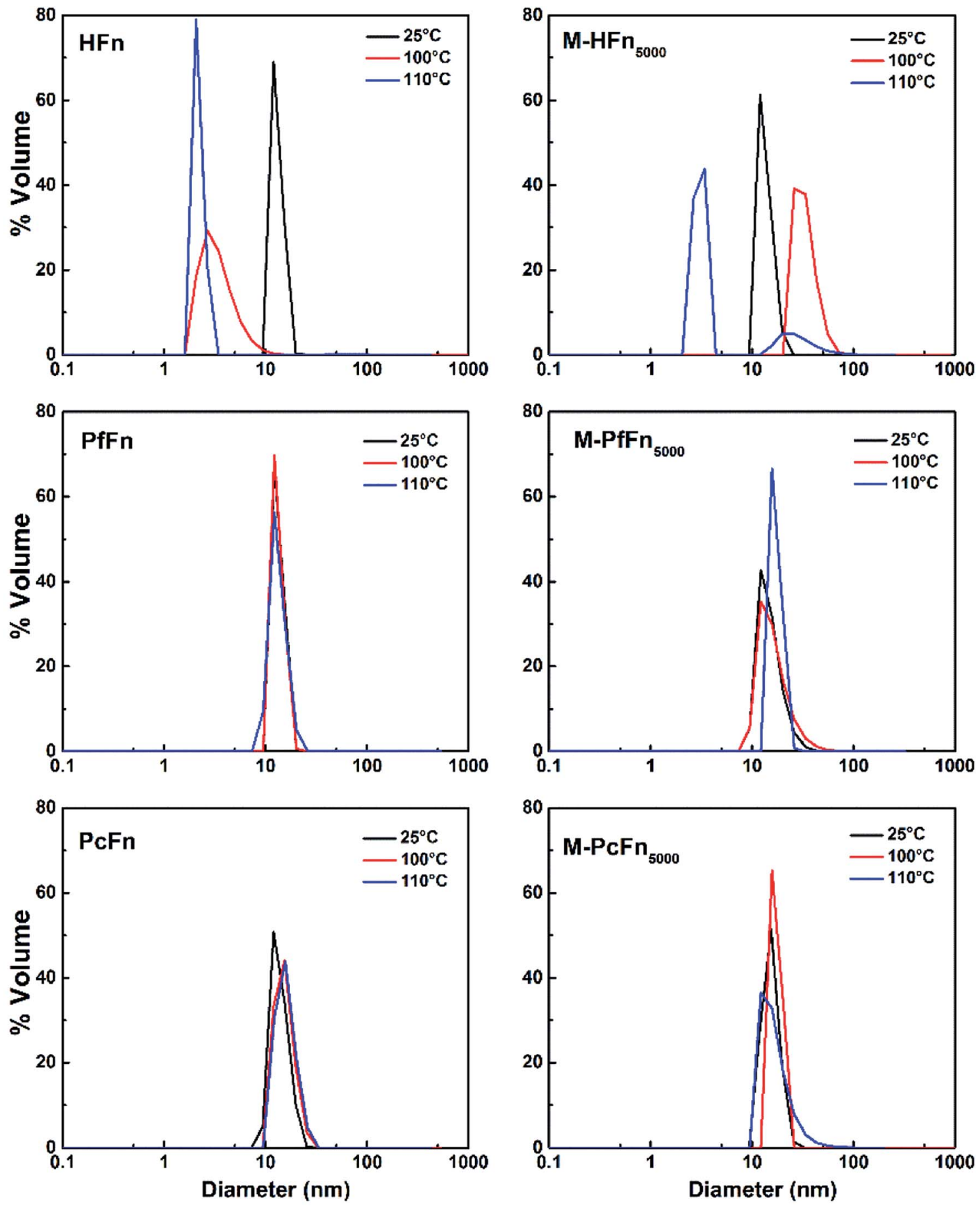

Fig. 7 DLS analysis of ferritins (HFn, PfFn, and PCFn) and magnetoferritins heated at $100^{\circ} \mathrm{C}$ (red plot) and $110^{\circ} \mathrm{C}$ (blue plot) for 30 min with a control group $\left(25^{\circ} \mathrm{C}\right)$ (black plot).

45.3\%, 16.3\%, and 16.5\%, respectively (Fig. S4†), while the $\alpha$ helical content of PcFn and PfFn heated to $120{ }^{\circ} \mathrm{C}$ was reduced to $34.5 \%$ and $34 \%$, respectively, indicating that the structures of PcFn and PfFn changed irreversibly at $120{ }^{\circ} \mathrm{C}$. This result is consistent with the DSC and protein concentration experiements.

DLS was performed to detect the hydrodynamic size distribution of ferritins in aqueous solution. ${ }^{44}$ As shown in Fig. 7 and
Table 4, the average hydrodynamic sizes of HFn, PfFn, and PcFn in $0.1 \mathrm{M} \mathrm{NaCl}$ before heating were $12.1 \mathrm{~nm}, 13.3 \mathrm{~nm}$, and $13.9 \mathrm{~nm}$, respectively. However, the size distribution of HFn was markedly altered toward smaller particles, with hydrodynamic sizes of $3.5 \mathrm{~nm}$ and $2.2 \mathrm{~nm}$ observed after heating at $100{ }^{\circ} \mathrm{C}$ and $110{ }^{\circ} \mathrm{C}$, respectively, for $30 \mathrm{~min}$. The sudden change in the hydrodynamic size of HFn is attributed to protein disassembly. In contrast, the hydrodynamic size of PfFn had no significant 
Table 4 The average hydrodynamic size of apoferritins and magnetoferritins $\left(0.5 \mathrm{mg} \mathrm{mL}^{-1}\right)$ in $0.1 \mathrm{M} \mathrm{NaCl}$ after heating (control group, $100{ }^{\circ} \mathrm{C}$, and $110^{\circ} \mathrm{C}$ ) for $30 \mathrm{~min}^{a}$

\begin{tabular}{|c|c|c|c|}
\hline $\begin{array}{l}\text { Sample } \\
\left(0.5 \mathrm{mg} \mathrm{mL}^{-1}\right)\end{array}$ & $\begin{array}{l}\text { HD before } \\
\text { heating (nm) }\end{array}$ & $\begin{array}{l}\text { HD after heating } \\
\text { at } 100{ }^{\circ} \mathrm{C}(\mathrm{nm})\end{array}$ & $\begin{array}{l}\text { HD after heating } \\
\text { at } 110{ }^{\circ} \mathrm{C}(\mathrm{nm})\end{array}$ \\
\hline HFn & 12.1 & 3.5 & 2.2 \\
\hline PfFn & 13.3 & 13.3 & 13.4 \\
\hline PcFn & 13.9 & 15.5 & 16.0 \\
\hline $\mathrm{M}-\mathrm{HFn}_{5000}$ & 13.6 & $3.1 / 29.5$ & 2.6/39.8 \\
\hline $\mathrm{M}-\mathrm{PfFn}_{5000}$ & 15.3 & 16.8 & 17.3 \\
\hline $\mathrm{M}-\mathrm{PcFn}_{5000}$ & 15.5 & 17.3 & 17.3 \\
\hline
\end{tabular}

Table 5 Hydrogen bonds in 24-mer of HFn, PcFn, and PfFn, calculated with HBPLUS ${ }^{a}$

\begin{tabular}{llllll}
\hline PDB ID & Sample & Total H-bonds $^{b}$ & MM & MS/SM & SS \\
\hline 2FHA & HFn & 2373 & 1309 & 894 & 415 \\
$-^{c}$ & PcFn & 2683 & 1648 & 958 & 690 \\
2JD6 & PfFn & 2788 & 2047 & 273 & 468
\end{tabular}

${ }^{a}$ MM: H-bonds between main-chain atoms only; MS/SM: H-bonds between main-chain and side-chain atoms; SS: $\mathrm{H}$-bonds between sidechain atoms only. ${ }^{b}$ Calculated using code: "HBPLUS-d 3.0". ${ }^{c}$ The PDB format file of predicted PcFn obtained from (https:// swissmodel.expasy.org/interactive/SEENpX/models/).

change before and after heating. And the hydrodynamic size of PcFn turned slight larger, to $15.5 \mathrm{~nm}$ and $16.0 \mathrm{~nm}$, after heating at $100{ }^{\circ} \mathrm{C}$ and $110{ }^{\circ} \mathrm{C}$, respectively.

The thermostability of a protein is determined by various factors, including hydrogen bonds, ${ }^{45-47}$ salt bridges ${ }^{48}$ and amino acid properties. ${ }^{49,50}$ By comparing the amino acid composition of mesophilic ferritin (HFn) with thermophilic ferritins (PcFn and PfFn) (Fig. S5 $†$ ), we found that the prevalence of fully charged residues (Glu, Arg, and Lys) ${ }^{51}$ is much higher in PcFn (24.3\%) and PfFn (24.1\%) than in HFn (16.4\%). It may be that the formation of extended networks of ion pairs by the charged groups represents a major stabilizing factor associated with adaptation to extreme temperatures. ${ }^{52,53}$ Additionally, we calculated the hydrogen bonds of the three ferritins with HBPLUS,$^{54}$ and found that the total hydrogen bonds in PcFn (2683) and PfFn (2788) are significantly more than that of HFn (2373), despite HFn have more residues than other two thermophiles ferritins. This may explain why PfFn and PcFn have much higher thermostability than HFn, and why the PfFn is slightly more stable than PcFn as the DSC and CD data shown. As shown in Table 5, the default program divides the hydrogen bonds results into three classes: between main-chain atoms only (MM); between main-chain and side-chain atoms (MS/SM); and between side-chain atoms only (SS). The MM hydrogen bonds are a dominant portion of total hydrogen bonds, which mainly influence the thermostability of protein. MS/SM hydrogen bonds may not be an important factor of thermostability because the PfFn has the lowest of it but with highest thermostability. Furthermore, a previous study reported the preferentially replacement of mesophilic protein residues: Gly to Ala, Ser to Ala, Ser to Thr, Lys to Arg, and Asp to Glu in a thermophilic protein, respectively, strengthening the internal and weakened external hydrophobicity, and also facilitated helix stabilizing in $\alpha$-helical proteins. ${ }^{55}$

\section{Thermostability of magnetoferritins}

Similar to the thermostability of ferritin cages above, mineralized $\mathrm{M}-\mathrm{PcFn}_{5000}$ and $\mathrm{M}-\mathrm{PfFn}_{5000}$ have much higher thermostability than M-HFn ${ }_{5000}$. DSC curves show that $T_{\mathrm{m}}$ values for M$\mathrm{PcFn}_{5000}\left(100.1^{\circ} \mathrm{C}\right)$ and $\mathrm{M}-\mathrm{PfFn}_{5000}\left(104.5^{\circ} \mathrm{C}\right)$ are much higher than for $\mathrm{M}-\mathrm{HFn}_{5000}\left(86.9^{\circ} \mathrm{C}\right)$ (Fig. 5 and Table 3), suggesting that $\mathrm{M}-\mathrm{PcFn}_{5000}$ and $\mathrm{M}-\mathrm{PfFn}_{5000}$ remained the strong thermostability of protein cages.

CD spectra (Fig. 6d and e) and $\alpha$-helical content results (Fig. S4b †ं) showed that the $\alpha$-helical content of $\mathrm{M}-\mathrm{PfFn}_{5000}$ decreased drastically with a temperature increased to $80{ }^{\circ} \mathrm{C}$, while the secondary structure of $\mathrm{M}-\mathrm{PfFn}_{5000}$ and $\mathrm{M}-\mathrm{PcFn}_{5000}$ were able to resist temperatures of $110{ }^{\circ} \mathrm{C}$. However, after heating at $120{ }^{\circ} \mathrm{C}$ for 30 minutes, the $\alpha$-helical content of MPfFn5000 and M-PcFn5000 had declined to $22.3 \%$ and $21.7 \%$ of their original $\alpha$-helical content, respectively.

As shown in Fig. 7 and Table 4, the hydrodynamic diameters of M-HFn $\mathrm{n}_{5000}$ increased from $13.6 \mathrm{~nm}$ before heating to $29.5 \mathrm{~nm}$ and $39.5 \mathrm{~nm}$ after heating at $100{ }^{\circ} \mathrm{C}$ and $110{ }^{\circ} \mathrm{C}$, respectively, due to disassembly of HFn protein cages and aggregation of proteins and the magnetite/maghemite cores. But the hydrodynamic diameters of $\mathrm{M}-\mathrm{PfFn}_{5000}$ and $\mathrm{M}-\mathrm{PcFn}_{5000}$ experienced no significant changes after heating to $100{ }^{\circ} \mathrm{C}$ and $110{ }^{\circ} \mathrm{C}$, indicating high thermostability of these two nanoparticles.

Moreover, we found that the $T_{\mathrm{m}}$ values for all the magnetoferritins ( $\mathrm{M}-\mathrm{HFn}_{5000}, \mathrm{M}-\mathrm{PfFn}_{5000}$, and $\mathrm{M}-\mathrm{PcFn}_{5000}$ ) declined $\left(4{ }^{\circ} \mathrm{C}, 12.3^{\circ} \mathrm{C}\right.$, and $11.9{ }^{\circ} \mathrm{C}$, respectively) compared with their apoferritins (HFn, PfFn, and PcFn), which has not been previously reported. An explanation might be that the inorganic inner core $\left(\mathrm{Fe}_{3} \mathrm{O}_{4}\right.$ or $\left.\gamma-\mathrm{Fe}_{2} \mathrm{O}_{3}\right)$ influenced the original connection of subunits of protein cage.

\section{Iron incorporation of ferritin cages}

To further investigate whether apo-ferritins retain ironincorporating ability after heating at high temperature, we performed iron incorporation experiments with each apoferritin before and after heating at $110{ }^{\circ} \mathrm{C}$, including a negative control that lacked apoferritins. A ferrihydrite core would be generated in the ferritin cage with the oxidation of $\mathrm{Fe}^{2+}$, and the absorbance obtained at $315 \mathrm{~nm}$ was used to quantify ferrihydrite. ${ }^{56}$ As expected, the HFn heated at $110{ }^{\circ} \mathrm{C}$ was unable to incorporate any $\mathrm{Fe}^{2+}$ due to disassembly of the protein cage. However, both of PcFn and PfFn exhibited the typical ability of iron incorporation after heating at $110{ }^{\circ} \mathrm{C}$. We calculated the velocity of the first two minutes $V_{0 \rightarrow 2 m i n}$ (micromol per L per $\mathrm{min}$ ) of ferrihydrite generation by determining the slope of each curve over the first two minutes. The PfFn and PcFn remained $86.3 \%$ and $87.4 \%$ of $V_{0 \rightarrow 2 \min }$, respectively (Fig. 8). 

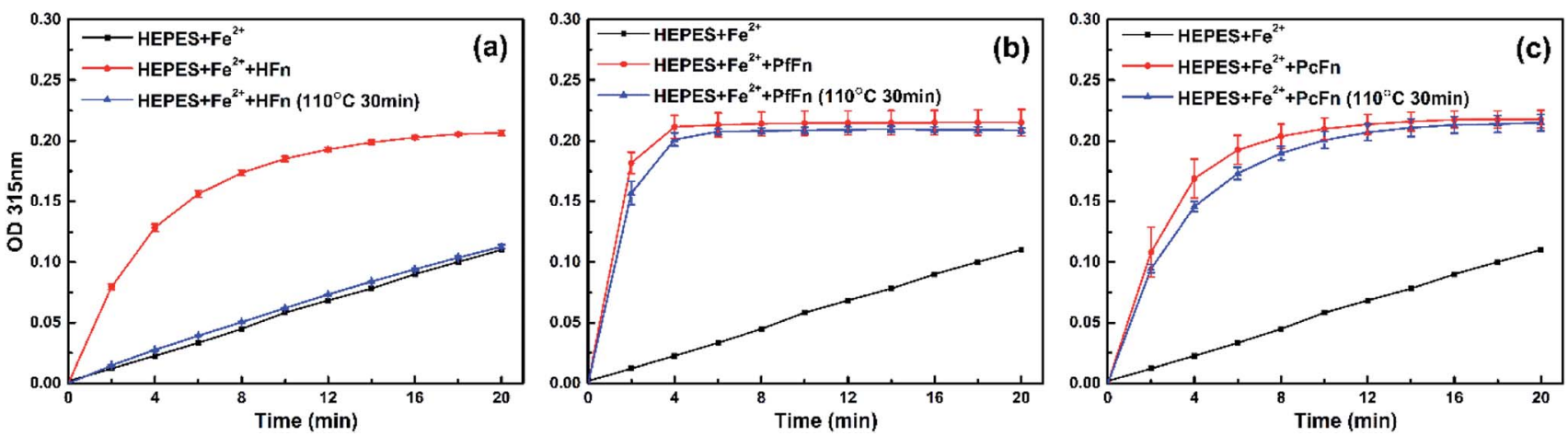

Fig. 8 A comparison of the iron uptake activity of ferritins: (a) HFn, (b) PfFn, and (c) PcFn before (red plot) and after (blue plot) heated at $110{ }^{\circ} \mathrm{C}$ for $30 \mathrm{~min}$. Black plot is control group without adding ferritin. The reactions were monitored in time scan mode at $315 \mathrm{~nm}$ for 20 min.

\section{Conclusion}

We have overexpressed a novel ferritin, PcFn, from hyperthermophilic archaeon Pyrococcus CH1 in E. coli BL21 (DE3), and successfully used PcFn as a template for synthesis of $\mathrm{M}$ $\mathrm{PcFn}_{5000}$ nanoparticles in vitro. To explore the structure, magnetic parameters, and thermostability of PcFn, we chose HFn and PfFn for comparisons, as the former is one of the moststudied mesophilic ferritins, and the latter is the most thermostable ferritin known to come from hyperthermophilic archaeon. TEM images and magnetic measurement results demonstrated that $\mathrm{M}-\mathrm{PcFn}_{5000}$ particles are superparamagnetic, monodispersed, and well-crystalline magnetite/maghemite nanoparticles with uniform shape and size distribution. In comparison with $\mathrm{HFn} / \mathrm{M}-\mathrm{HFn}_{5000}$ and $\mathrm{PfFn} / \mathrm{M}-\mathrm{PfFn}_{5000}$, the thermostability of both PcFn and $\mathrm{M}-\mathrm{PcFn}_{5000}$ was as high as $110{ }^{\circ} \mathrm{C}$. After heating of the PcFn at $110^{\circ} \mathrm{C}$ for $30 \mathrm{~min}$, it still maintained $87.4 \%$ of $V_{0 \rightarrow 2 \mathrm{~min}}$ for iron incorporation ability. These encouraging findings open up the possibility of using PcFn as a new nanoplatform for controlled synthesis of thermostable nanoparticles for application in elevated temperature systems.

\section{Conflicts of interest}

There are no conflicts of interest to declare.

\section{Acknowledgements}

This work was supported by National Natural Science Foundation of China (NSFC) grants (41574062, 41774076, 41621004), Key Program of Chinese Academy of Sciences (QYZDJ-SSWDQC024). We are grateful to $\mathrm{Xu}$ Tang from the Institute of Geology and Geophysics, Chinese Academy of Sciences for helping capture the high resolution TEM images, and we are grateful to B. X. Huangfu from the Institute of Biophysics, Chinese Academy of Sciences for helping with preparation of the negative-stained samples. We thank professor Xiang Xiao from Shanghai Jiaotong University for kindly sharing the gene sequence of PcFn with us. We also thank Yan Ma from Institute of Geology, China Earthquake Administration for help in the iron content measurement by ICP-OES.

\section{References}

1 H. G. Bagaria, K. Y. Yoon, B. M. Neilson, V. Cheng, J. H. Lee, A. J. Worthen, Z. Xue, C. Huh, S. L. Bryant, C. W. Bielawski and K. P. Johnston, Langmuir, 2013, 29, 3195-3206.

2 C. Kotsmar, K. Y. Yoon, H. Yu, S. Y. Ryoo, J. Barth, S. Shao, M. a. Prodanović, T. E. Milner, S. L. Bryant and C. Huh, Ind. Eng. Chem. Res., 2010, 49, 12435-12443.

3 M. Iqbal, B. A. Lyon, E. E. Ureña-Benavides, E. Moaseri, Y. Fei, C. McFadden, K. J. Javier, C. J. Ellison, K. D. Pennell and K. P. Johnston, Colloids Surf., A, 2017, 520, 257-267.

4 A. R. Rahmani, S. Bryant, C. Huh, A. Athey, M. Ahmadian, J. Chen and M. Wilt, SPE J., 2015, 20, 1067-1082.

5 A. Karimi, Z. Eftekhari, M. Karimi and Z. Dalirnasab, Synthesis, 2014, 46, 3180-3184.

6 W. Li, B. Zhang, X. Li, H. Zhang and Q. Zhang, Appl. Catal., A, 2013, 459, 65-72.

7 K. Y. Yoon, C. Kotsmar, D. R. Ingram, C. Huh, S. L. Bryant, T. E. Milner and K. P. Johnston, Langmuir, 2011, 27, 1096210969.

8 S. Ryoo, A. R. Rahmani, K. Y. Yoon, M. Prodanović, C. Kotsmar, T. E. Milner, K. P. Johnston, S. L. Bryant and C. Huh, J. Pet. Sci. Eng., 2012, 81, 129-144.

9 P. Arosio, R. Ingrassia and P. Cavadini, Biochim. Biophys. Acta, Gen. Subj., 2009, 1790, 589-599.

10 H.-A. Hosein, D. R. Strongin, M. Allen and T. Douglas, Langmuir, 2004, 20, 10283-10287.

11 F. C. Meldrum, B. R. Heywood and S. Mann, Science, 1992, 257, 522-523.

12 T. Douglas and V. T. Stark, Inorg. Chem., 2000, 39, 18281830.

13 C. C. Jolley, M. Uchida, C. Reichhardt, R. Harrington, S. Kang, M. T. Klem, J. B. Parise and T. Douglas, Chem. Mater., 2010, 22, 4612-4618.

14 H. Fukano, T. Takahashi, M. Aizawa and H. Yoshimura, Inorg. Chem., 2011, 50, 6526-6532.

15 I. Yamashita, J. Hayashi and M. Hara, Chem. Lett., 2004, 33, 1158-1159. 
16 S. Li, A. R. Lee, J. H. Kim and S. J. Park, Sci. Adv. Mater., 2015, 7, 2743-2746.

17 K. W. Pulsipher, S. Honig, S. Deng and I. J. Dmochowski, J. Inorg. Biochem., 2017, 174, 169-176.

18 K. Fan, C. Cao, Y. Pan, D. Lu, D. Yang, J. Feng, L. Song, M. Liang and X. Yan, Nat. Nanotechnol., 2012, 7, 459-464.

19 C. Cao, X. Wang, Y. Cai, L. Sun, L. Tian, H. Wu, X. He, H. Lei, W. Liu, G. Chen, R. Zhu and Y. Pan, Adv. Mater., 2014, 26, 2566-2571.

20 Y. Cai, Y. Wang, H. Xu, C. Cao, R. Zhu, X. Tang, T. Zhang and Y. Pan, Nanoscale, 2019, 11, 2644-2654.

21 E. Fantechi, C. Innocenti, M. Zanardelli, M. Fittipaldi, E. Falvo, M. Carbo, V. Shullani, L. D. Mannelli, C. Ghelardini, A. M. Ferretti, A. Ponti, C. Sangregorio and P. Ceci, ACS Nano, 2014, 8, 4705-4719.

22 S. Stefanini, S. Cavallo, C.-Q. Wang, P. Tataseo, P. Vecchini, A. Giartosio and E. Chiancone, Arch. Biochem. Biophys., 1996, 325, 58-64.

23 F. Zhang, Y. H. She, H. M. Li, X. T. Zhang, F. C. Shu, Z. L. Wang, L. J. Yu and D. J. Hou, Appl. Microbiol. Biotechnol., 2012, 95, 811-821.

24 R. Yang, P. Zuo, M. Zhang, D. Meng, B. Wang and T. Zhen, Food Hydrocolloids, 2019, 94, 500-509.

25 S.-W. Kim, Y.-H. Kim and J. Lee, Biochem. Biophys. Res. Commun., 2001, 289, 125-129.

26 G. Fiala and K. O. Stetter, Arch. Microbiol., 1986, 145, 56-61. 27 K. S. Lundberg, D. D. Shoemaker, M. W. W. Adams, J. M. Short, J. A. Sorge and E. J. Mathur, Gene, 1991, 108, $1-6$.

28 J. Tatur, P. L. Hagedoorn, M. L. Overeijnder and W. R. Hagen, Extremophiles, 2006, 10, 139-148.

29 J. Tatur, W. R. Hagen and P. M. Matias, J. Biol. Inorg Chem., 2007, 12, 615-630.

30 M. J. Parker, M. A. Allen, B. Ramsay, M. T. Klem, M. Young and T. Douglas, Chem. Mater., 2008, 20, 1541-1547.

31 E. Johnson, D. Cascio, M. R. Sawaya, M. Gingery and I. Schroder, Structure, 2005, 13, 637-648.

32 S. Tetter and D. Hilvert, Angew. Chem., Int. Ed. Engl., 2017, 56, 14933-14936.

33 X. Zeng, J. L. Birrien, Y. Fouquet, G. Cherkashov, M. Jebbar, J. Querellou, P. Oger, M. A. Cambon-Bonavita, X. Xiao and D. Prieur, ISME J., 2009, 3, 873-876.

34 G. Michoud and M. Jebbar, Sci. Rep., 2016, 6, 27289.

35 X. Jun, L. Lupeng, X. Minjuan, P. Oger, W. Fengping, M. Jebbar and X. Xiang, J. Bacteriol., 2011, 193, 4297-4298.
36 Y. Cai, C. Cao, X. He, C. Yang, L. Tian, R. Zhu and Y. Pan, Int. J. Nanomed., 2015, 10, 2619-2634.

37 T. Zhang, C. Cao, X. Tang, Y. Cai, C. Yang and Y. Pan, Nanotechnology, 2017, 28, 045704.

38 B. Jiang, L. Yan, J. Zhang, M. Zhou, G. Shi, X. Tian, K. Fan, C. Hao and X. Yan, ACS Appl. Mater. Interfaces, 2019, 11, 9747-9755.

39 C. Yang, C. Cao, Y. Cai, H. Xu, T. Zhang and Y. Pan, J. Nanopart. Res., 2017, 19, 101.

40 T. Zhang and Y. Pan, Earth, Planets Space, 2018, 70, 206.

41 C. Cao, L. Tian, Q. Liu, W. Liu, G. Chen and Y. Pan, J. Geophys. Res., 2010, 115, В07103.

42 E. P. Wohlfarth, J. Appl. Phys., 1958, 29, 595-596.

43 S. W. Kim, Y. H. Kim and J. Lee, Biochem. Biophys. Res. Commun., 2001, 289, 125-129.

44 R. Yang, L. Chen, T. Zhang, S. Yang, X. Leng and G. Zhao, Chem. Commun., 2014, 50, 481-483.

45 J. K. Myers and C. N. Pace, Biophys. J., 1996, 71, 2033-2039. 46 G. Vogt, S. Woell and P. Argos, J. Mol. Biol., 1997, 269, 631643.

47 L. Bleicher, E. T. Prates, T. C. Gomes, R. L. Silveira, A. S. Nascimento, A. L. Rojas, A. Golubev, L. Martínez, M. S. Skaf and I. Polikarpov, J. Phys. Chem. B, 2011, 115, 7940-7949.

48 P. Strop and S. L. Mayo, Biochemistry, 2000, 39, 1251-1255.

49 M. M. Gromiha, M. Oobatake, H. Kono, H. Uedaira and A. Sarai, J. Protein Chem., 1999, 18, 565-578.

50 M. M. Gromiha, M. Oobatake and A. Sarai, Biophys. Chem., 1999, 82, 51-67.

51 D. R. Tompa, M. M. Gromiha and K. Saraboji, J. Mol. Graphics Modell., 2016, 64, 85-93.

52 K. Yip, T. Stillman, K. Britton, P. Artymiuk, P. Baker, S. Sedelnikova, P. Engel, A. Pasquo, R. Chiaraluce and V. Consalvi, Structure, 1995, 3, 1147-1158.

53 P. J. Haney, J. H. Badger, G. L. Buldak, C. I. Reich, C. R. Woese and G. J. Olsen, Proc. Natl. Acad. Sci. U. S. A., 1999, 96, 3578-3583.

54 I. K. McDonald and J. M. Thornton, J. Mol. Biol., 1994, 238, 777-793.

55 P. Argos, M. G. Rossmann, U. M. Grau, H. Zuber, G. Frank and J. D. Tratschin, Biochemistry, 1979, 18, 5698-5703.

56 F. Bonomi, D. M. Kurtz Jr and X. Cui, JBIC, J. Biol. Inorg. Chem., 1996, 1, 67-72. 